\title{
Testing the Relationship between Corporate Governance and Bank Performance - An Empirical Study on Vietnamese Banks
}

\author{
Tran Thi Thanh Tu${ }^{1}$, Nguyen Hong Son ${ }^{1} \&$ Pham Bao Khanh ${ }^{2}$ \\ ${ }^{1}$ VNU University of Economics and Business, Vietnam \\ ${ }^{2}$ Deposit Insurance of Vietnam, Vietnam \\ Correspondence: Tran Thi Thanh Tu, VNU University of Economics and Business, Vietnam. E-mail: \\ tuttt@vnu.edu.vn
}

Received: March 13, 2014 Accepted: March 25, $2014 \quad$ Online Published: April 29, 2014

doi:10.5539/ass.v10n9p213 URL: http://dx.doi.org/10.5539/ass.v10n9p213

\begin{abstract}
The paper examines the impact of corporate governance on performance of Vietnamese banks. The Corporate Governance Index has been used to evaluate corporate governance of Vietnamese banks in the period of 2010-2012. The return on equity and return on assets have been used to measure the bank performance. It is found that there is a significant gap between actual practices of corporate governance of Vietnamese banks and the international principles, a statistically significant difference in corporate governance of listed banks and non-listed banks in Vietnam. Better corporate governance is associated with better performance. The authors also have found the positive correlation of disclosure, the role of board of directors, shareholders and shareholder meetings with bank performance in Vietnamese banks. The relationship between supervisory board and bank performance has not been found. These findings lay a foundation for policy makers to make necessary changes to improve corporate governance (i.e role of Board of directors, disclosure and shareholder issues) of banks in Vietnam in the current restructure of the banking system.
\end{abstract}

Keywords: corporate governance, disclosure, bank performance, board of director

\section{Introduction}

The Vietnam banking system has experienced many changes since 2008. The change in ownership structure and governance is one of them. Establishment of joint stock banks, privatization of 3 largest state owned commercial banks and issuance of new law on credit institutions in 2010 are milestones of the changing process. In this context, corporate governance in Vietnam banking system, an element which contributes to stability of the banking system, has been improved. However, bank governance is required to have fundamental changes so that it can become a motive for sustainability and stability of the banking system.

Corporate governance of businesses is usually evaluated based on a framework such as OECD principles (OECD, 2006) or measured by an index. Corporate governance index (CGI) has been used in many countries. In Vietnam, CGI has not been introduced. It is necessary to introduce this index in order to promote transparency and strength of the Vietnam banking system in the globalization process.

While corporate governance in Vietnam banking system has been one of the major concerns of all market participants, research in this area is limited. Several research projects and surveys in corporate governance of Vietnam enterprises highlighted that there is a big gap between the international principles and Vietnam regulations and a substantial deviation of actual practices from regulation (Cung \& Robertson, 2005; Freeman \& Lan, 2006). However, there has not been a quantitative research in corporate governance and its relationship with performance in the Vietnam banking system.

Brief review of literature in other countries indicated that there is no conclusive finding of the relationship corporate governance and bank performance. The results are mixed depending on time of data and country specific conditions.

Based on the above two research gaps in corporate governance and the context of Vietnam banking system, this paper intends to evaluate the corporate governance of Vietnamese banks by proposing a method to construct a Corporate Governance Index (CGI) and testing the relationship between corporate governance (using CGI) and bank performance. The results will provide some exploratory information for further empirical studies and bank 
regulation in Vietnam.

This paper is constructed as follows: Following the introduction, the second session reviews researches relating to corporate governance, corporate governance index (CGI) and relationship between corporate governance and bank performance, the third session proposes the methodology to build CGI of Vietnamese banks and the model to test the relationship between CGI and bank performance. The fourth session presents the research results and discussions. The final session proposes some recommendations to improve corporate governance and performance of Vietnamese banks.

\section{Literature review}

\subsection{Definition of Corporate Governance}

There are many definitions of corporate governance. OECD (2004) states that "Corporate governance is a system by which companies are directed and controlled". La Porta et al. (2000) consider corporate governance as a set of mechanisms in which outside investors protect themselves against problems arising from conflicts of interest from the managers and controlling shareholders. Although there are different definitions of corporate governance, according to Pei Sai Fan (2004), "corporate governance is basically about putting in place the structure, processes and mechanisms by which business and affairs of the company are directed and managed in order to enhance the long term shareholder value through accountability of managers".

At basic level, corporate governance problems arise when shareholders wish to control their companies in a different way to the managers. These problems are further complicated by conflicts among different shareholders due to the diversity in ownership. To solve these conflicts, proper corporate governance frameworks are put in place. Five mechanisms in corporate governance are used to manage the conflicts: (i) hostile takeover, (ii) partial concentration ownership and control in large shareholders or a group of shareholders, (iii) delegation of partial control to large creditors (e.g. financial intermediaries), (iv) Control of CEO by board of directors, (v) alignment manager's interests with shareholder through remuneration policy. Among these mechanisms, the role of board of directors in controlling CEOs is widely used. Most corporate charters require that shareholders elect a board of directors, which monitors the CEO on their behalf.

\subsection{The Role of Board of Director and Disclosure in Corporate Governance}

Research in the field of board of directors has focused on the board composition and independence. The impact of independent directors on efficiency of the boards has been studied based on empirical data. The results are mixed. On the one hand, practical findings support the hypothesis that independent directors gave rise to an improvement in board efficiency. For example, the board with higher independence can replace inefficient CEOs more easily. On the other hand, other evidence suggested that there is no conclusive evidence on the effect of board independence (Becht, 2007; Hermanlin \& Weisbach, 1991).

In banking, the role of boards is of special importance and relevance. This is because there is limited competition, intense regulation and high information asymmetry which complicate the issue of bank governance (Levine, 2004). Researches in the role of board of directors in banks also centered on board composition and independence. The bank board composition and size are found to be related to the abilities of the board in monitoring CEOs. However, excessive independent directors can negatively affect board efficiency. The suggested optimum limit for the board of an international bank is 19 directors (Andres \& Vallelado, 2008).

In Asian banks, researches in corporate governance found that the boards in Japanese banks did not fulfill their duty of monitoring properly especially before the financial crisis. CEOs were found to be unrelated to dismissal discipline because of poor performance. After the crisis, the situation changed since the higher the number of directors replaced, the higher performance the bank experienced (Anderson \& Campbell, 2004). In South East Asia, privatization of banks is found to bring about better performance (William \& Nguyen, 2005). This finding suggests that increasing control of the boards as a consequence of privatization has improved the bank performance.

In contrast to extensive literature on the role of the board, there is limited analysis of the role of the boards and how the boards should be regulated in practice. In Vietnam, there is no analysis or evaluation of regulations of corporate governance in banks. However, the assessment of the corporate governance of Vietnam market against OECD principles by the World Bank in 2006 highlighted a significant gap between the Vietnam practices and OCED principles in corporate governance (World Bank, 2006).

Many previous studies had indicated the relationship between disclosure practice and corporate governance. Lowenstein (1996) argued that good disclosure has been the most efficient and effective mechanism for inducing managers to manage better. This implies that firms with better information disclosure may have better corporate 
governance. Therefore, disclosure and transparency contribute a significant part in terms of corporate governance in particular and the organizations in general.

Disclosing relevant information enhances transparency and provides adequate information, thus helping the company's stakeholders and other market participants to act accordingly (Rahman, 2006). In addition, corporate governance disclosure is important for investors to get a good picture of the level of monitoring activities. It also helps investors to identify and compare the corporate governance practices among different companies. Subsequently, investors can choose the best alternative investment based on the level of corporate covernance disclosure (Rahman \& Salim, 2010). Therefore, corporate governance serves as a mechanism to mitigate agency problems between the shareholders and management. Improvements in corporate disclosure practices and establishment of guidelines for governing companies are expected to assist the shareholders to ensure that the management will act at the interest of shareholders. Only through full and complete disclosure and transparent management practices, can shareholders feel confident that the firm to which they have given their funds is being operated with their best interests in mind.

\subsection{Constructing the Corporate Governance Index (CGI)}

Two main types of CGI have been studied and built by researches and projects: (i) CGI built by individual country such as the United Kingdom, Japan, Singapore, Turkey, (ii) CGI of a group of countries such as CGI Euro, CGI of developed countries (ISS \& FTSE, 2005). From index's content perspective, there is an index of certain area in corporate governance such as index of investors' right protection, index of disclosure and transparency (Marina \& Luc, 2005) and composite index such as GTI of Singapore (The business Times and CGIO, 2011).

In principles, most CGI are measured based on corporate governance principles such as OECD principles. However, it is recognized from projects and researches that methodology to construct CGI differs in terms of measurement indicators and calculation method. For instance, Singapore CGI (GTI) has 21 indicators while CGI of a group of countries uses 49 indicators. This indicates that CGI depends on national conditions. Each country should have its own studies in CGI.

In Vietnam, there is a growing number of researches in corporate governance. Assessment reports of corporate governance in Vietnam (World Bank, 2006; Cung \& Scott, 2005) have concluded that Vietnam has not materially observed most of OECD corporate governance principles; regulations in corporate governance have not been complied well in Vietnam. Quach (2008) and Lê (2009) have found that corporate governance has impact on firm performance. The state research project in building corporate governance index (2010) by Truong has proposed as set of indicators and methodology to calculate CGI for Vietnam.

In banking, researches in corporate governance mainly focus on qualitative assessment of actual practices. It is widely agreed that there is a big gap between OECD principles and regulation in bank governance in Vietnam. It is found that the board independence is weak, minority shareholders' rights are not well protected, disclosure and transparency is inadequate and inaccurate. It is also found that becoming listed and privatization has improved bank governance for the past few years (Tran \& Pham, 2012). Together with OECD principles, Basel principles of enhancing corporate governance in banking have formed a framework for bank governance. However, an assessment based on these principles is qualitative and it is not easy to make comparison of corporate governance among banks. Furthermore, proposed CGI construction method by Truong (2010) only covers corporate governance of companies in general which does not take into account specific regulations for banks. Like other countries, banking system in Vietnam is highly regulated compared to other businesses which makes bank governance differs substantially to other businesses. In this context, it is necessary to have a CGI for banks. The authors have proposed a set of indicators and calculation method to construct a CGI and used them to construct CGI for all Vietnam banks (Tran \& Pham, 2012). The research result is good as information to build the index can be considered as adequate. It has shown the clear difference between corporate governance in Vietnam Banks and international standards in that the scores are substantially below the maximum level. However, in scoring the index, some indicators need to be modified and an in-depth qualitative evaluation of individual bank corporate governance is needed in order to have some insights in appropriateness of CGI and in how each indicator is evaluated before deciding its score.

\subsection{The Relationship between CGI and Disclosure As Well As Board of Directors and Bank Performance}

Many researches study the relationship between corporate governance and firm efficiency. There are two main streams of approach in these researches. One is to study this relationship in one or two aspects of corporate governance such as board independence, transparency and disclosure. The other is to have overall assessment of corporate governance by an index. 
For the first approach, researches in the role of board of directors in banks focused on board composition and independence. The bank board composition and size is found to be related to the abilities of the board in monitoring CEOs. However, excessive independent directors can negatively affect board efficiency. The suggested optimum limit for the board of an international bank is 19 directors (Andres \& Vallelado, 2008).

In Asian banks, researches in corporate governance found that the boards in Japanese banks did not fulfill their duty of monitoring properly especially before the financial crisis. CEOs were found to be unrelated to dismissal discipline because of poor performance. After the crisis, the situation changed since the higher the number of directors replaced, the higher performance the bank experienced (Anderson \& Campbell, 2004). In South East Asia, privatization of banks is found to bring about better performance (William \& Nguyen, 2005). This finding suggests that increasing control of the boards as a consequence of privatization has improved the bank efficiency.

For the second approach, researches focus on relationship of corporate governance (represented by corporate governance index) and firm performance. Many researches use correlation and regression in examining the relationship. The results are mixed subject to time of data and country specific condition. Gompers, Ishii \& Metrick (2003) examined relationship between corporate governance and firm performance of listed 1,500 large US firms. The corporate governance index including voting rights, takeover defense etc. is used as proxy for corporate governance. Performance is measured by Tobins Q, profit, sale growth. It was found that firms with stronger shareholder rights had higher firm value i.e Tobin's Q, higher profits, higher sales growth, lower capital expenditures.

Brown \& Caylor (2004) also studied relationship between their corporate governance index (Gov-Score) and US firm performance represented by operational performance (return on equity, net profit margin, sales growth), valuation (Tobin's Q) and shareholder payout (dividend yield and stock repurchases). The results showed that in 2002, low Gov - Score firms were identified with lower operating performance (lower return on equity and lower net profit margin), lower valuations (lower Tobin's Q) and paid out less cash to their shareholders.

Epps \& Cereola (2008) analysed the relationship between corporate governance and firm performance using Corporate Governance Quotient, provided by Institutional Shareholder Services for more than 800 US firms in 2002 - 2004. The result showed that there was no relationship between firm performance and corporate governance rating.

Differently of previous studies, Daines, Gow \& Larcker (2008), used commercial corporate governance rating provided by specialized companies to analyze their predictive ability during the period 2005-2007 for nearly 7,000 U.S. firms. The authors used the following commercial ratings: Audit Integrity(AGR), Risk Metrics/ISS (CGQ), Governance Metrics International (GMI), and The Corporate Library (TCL). Performance is represented by operational performance (represented by return on assets), valuation (represented by Tobin's Q, and excess stock returns). The study found that higher CGQ seemed to be identified with lower Tobin's Q. These mixed results were possibly explained by 2 reasons: (i) corporate governance was an endogenous choice by firms or (2) There were measurement errors in corporate governance rating.

Similar to Daines, Gow \& Larcker (2009), Vintila. G and Gherghina (2012) investigated the empirical relationship between corporate governance ratings and performance of companies listed on America stock exchanges. Research results find a negative relationship between corporate governance sub -indices (Audit, board structure, shareholder rights, and compensation, provided by Institutional Shareholder Services) and firm performance. CGI is negatively correlated with financial leverage, Tobin's Q but positively correlated with company size. With regression, the researchers found that $1 \%$ increase of CGI will decrease $4 \%$ of Tobin's Q, $1 \%$ increase of CGI will decrease $9 \%$ of book value. The relationship between CGI and ROA was not identified. In contrast, Black and Jang Hasung (2003) examined the impact of corporate governance on firm value in Korea. The results show a positive relationship between corporate governance index and market/book ratio and Tobin's Q. Another study by Anderson and Gupta (2009) compares a cross-country of corporate governance (represented by corporate governance quotient) and firm performance. The results show that the relationship can be positive or negative depending on country's financial structure (bank based or not) and legal system.

As a result of all above findings, it is necessary to examine the relationship between corporate governance (measured by CGI) and bank performance in Vietnam while the banking system has undergone restructuring process. From the literature review, it's found that there has never been a quantitative research on the impact of corporate governance of banks, and different components of corporate governance of banks in Vietnam on their performance. This paper will contribute to the literature review on finding of these impacts in terms of testing whether the positive correlation between components of corporate governance found in the previous researches in 
the world has been found in Vietnamese banks. These findings will help the authors to suggest policy recommendations for improvement of transparency, accountability, and performance of banks in Vietnam, which could be valuable for policy makers in the context of bank restructuring in Vietnam nowadays. In addition, the findings will provide an additional empirical evidence in corporate governance in a developing Asian country which help form the foundation for literature in corporate governance.

\section{Hypothesis Development, Data and Research Methodology}

\subsection{Hypothesis Development}

The above review of related researches has shown that corporate governance has either positive or negative relationship with firm performance depending on time of the data and specific conditions of each market. However, more researches have found positive relationship than the negative ones. For this reason, the following hypothesizes developed:

Hypothesis 1: There is a positive relationship between corporate governance and bank performance

In Vietnam, 2005 is the year that the first bank was listed on the stock exchange market. In 2013, there are 10 banks listed. Listed banks are required to comply with stricter regulation than non listed banks. Therefore, it is expected that corporate governance of listed bank is better than non listed banks. For this reason, the following hypothesis is developed:

Hypothesis 2: There is a difference in corporate governance between listed and no listed banks

The above review of related research also found the relationship between corporate governance and equity size, asset size. For this reason, the following hypothesis is developed:

Hypothesis 3: There is a difference in corporate governance between banks with larger equity and others.

Hypothesis 4: There is a difference in corporate governance between banks with larger assets and others

\subsection{Data}

Secondary information and data of the banks includes the bank annual report, audited financial reports, reports and other materials in general shareholders' meeting (GSM), other information from the bank website and other related websites.

Primary data includes 22 in-depth interviews with banks in Hanoi and HoChiMinh City conducted from July to October 2013 to find the detailed information on corporate governance of banks

With this information, CGI of 39 of total 44 Vietnamese Banks has been calculated for 2010 and 2011 respectively, 32 banks for 2012. Therefore, the total sample is 110. However, as 3 banks do not have accurate data to test the difference in corporate governance between bank with different asset, capital. Therefore, in testing hypothesis $2,3,4,75$ banks are used in the sample.

\subsection{Research Methodology}

Proposed corporate governance index construction method

To test all hypothesis, corporate governance of banks is measured by corporate governance index (CGI). Based on Corporate Governance Scorecard of Vietnam 2011 by International Finance Corporation (IFC, 2011) and proposed CGI for Vietnamese listed companies (Thang, 2010) and Basel principles for enhancing corporate governance (OECD, 2006), CGI was first developed by the authors in 2012 and modified after that to be used for this study (Tu \& Khanh, 2012).

CGI is measured based on 60 questions which cover 5 main components:

- Shareholders and general shareholders' meeting (18 questions)

- Board of directors (20 questions)

- Supervisory board (8 questions)

- Disclosure and transparency, auditing (12 questions)

- Violations (2 questions)

Questions are designed to be straight forward, based on published information. Each question is marked based on marking scale. The maximum score is 100 . If banks are found to have any violation of regulations, their scores will be deducted. 
Table 1. Scoring scale

\begin{tabular}{lc}
\hline Component & Point \\
\hline Shareholders and general shareholders' meeting & 37 \\
Board of directors & 34 \\
Supervisory board & 8 \\
Disclosure and transparency, auditing & 21 \\
Violations & -2 \\
\hline
\end{tabular}

\section{Analysis Methods}

To test four hypotheses, the following methods are going to be used:

For Hypothesis 1: Ordinary least squares is used to examine the relationship between corporate governance and bank performance.

Linear regression is going to be used to examine the relationship between corporate governance and bank performance for 3 years $(2010,2011,2012)$. The following models used in this study are mainly based on model of Vintila. G and Gherghina (2012). The variables are selected based on the previous researches (Daines, Gow \& Larcker (2008), Vintila. G and Gherghina (2012), Gompers, Ishii \& Metrick (2003), Brown \& Caylor (2004), Daines, Gow \& Larcker (2008), Epps \& Cereola (2008) and adjusted due to availability of data in Vietnam.

$\mathrm{ROE}=\beta_{0}+\beta_{1} \mathrm{x}$ CGI (or component CGI) $+\beta_{2} \mathrm{xLEV}+\beta_{3} \mathrm{x} \ln$ assets $+\mathrm{E}$ (residual)

$\mathrm{ROA}=\beta_{0}+\beta_{1} \mathrm{x}$ CGI (or component CGI) $+\beta_{2} \mathrm{xLEV}+\beta_{3} \mathrm{x}$ ln assets $+\mathrm{E}$ (residual)

In which,

\section{Dependent variable:}

Bank performance: measured by - ROE, ROA, Cost to income.

ROE, ROA are popular ratios to measure net income on equity and net income on total assets. These ratios reflect the ability of a bank to generate return on equity and the investment portfolio of a bank.

\section{Independent variables:}

Corporate governance: Corporate governance index (CGI) has been calculated for each bank by the above proposed methodology. Besides CGI, we break down into 4 main components of CGI including: shareholders, board of directors, supervisory board, disclosure to test impact of each component on bank performance for deeper explanation on the corporate governance in Vietnamese banks.

\begin{tabular}{|c|c|c|}
\hline Dependent variable & Calculation & \\
\hline $\begin{array}{l}\text { ROE - Return on Equity } \\
\text { ROA - Return on Asset }\end{array}$ & $\begin{array}{l}\text { Net income/ Total Equity } \\
\text { Net income/ Total asset }\end{array}$ & \\
\hline Independent variable & Calculation & Suggested relationship \\
\hline TA - Total Assets & & Positive/Negative \\
\hline LEV- leverage ratio & Equity/ Total Assets & Positive \\
\hline CGI - corporate governance index & $\begin{array}{l}\text { Evaluated from the questionnaire to } \\
\text { banks by the authors, in } \\
\text { consolidation from } 5 \text { components }\end{array}$ & \\
\hline CGI component - shareholder (CGI 1) & $\begin{array}{l}\text { Evaluated from the questionnaire to } \\
\text { banks by the authors }\end{array}$ & Positive \\
\hline $\begin{array}{l}\text { CGI component } \\
\text { - Board of Director (CGI 2) }\end{array}$ & $\begin{array}{l}\text { Evaluated from the questionnaire to } \\
\text { banks by the authors }\end{array}$ & Positive \\
\hline CGI component - Supervisory Board (CGI 3) & $\begin{array}{l}\text { Evaluated from the questionnaire to } \\
\text { banks by the authors }\end{array}$ & Positive \\
\hline CGI component - Disclosure and transparency, auditing (CGI 4) & $\begin{array}{l}\text { Evaluated from the questionnaire to } \\
\text { banks by the authors }\end{array}$ & Positive \\
\hline
\end{tabular}


For Hypothesis 2, 3, 4: One way ANOVA is used to test whether there is a difference in corporate governance between banks with listed/non listed status, different assets and equity.

\section{Research Results and Discussions}

\subsection{Descriptive Statistics}

Descriptive statistics of our measures of corporate governance is presented in table 2, bank performance, leverage, total asset and equity in table 3 and table 4 .

Table 2. Descriptive statistics of CGI

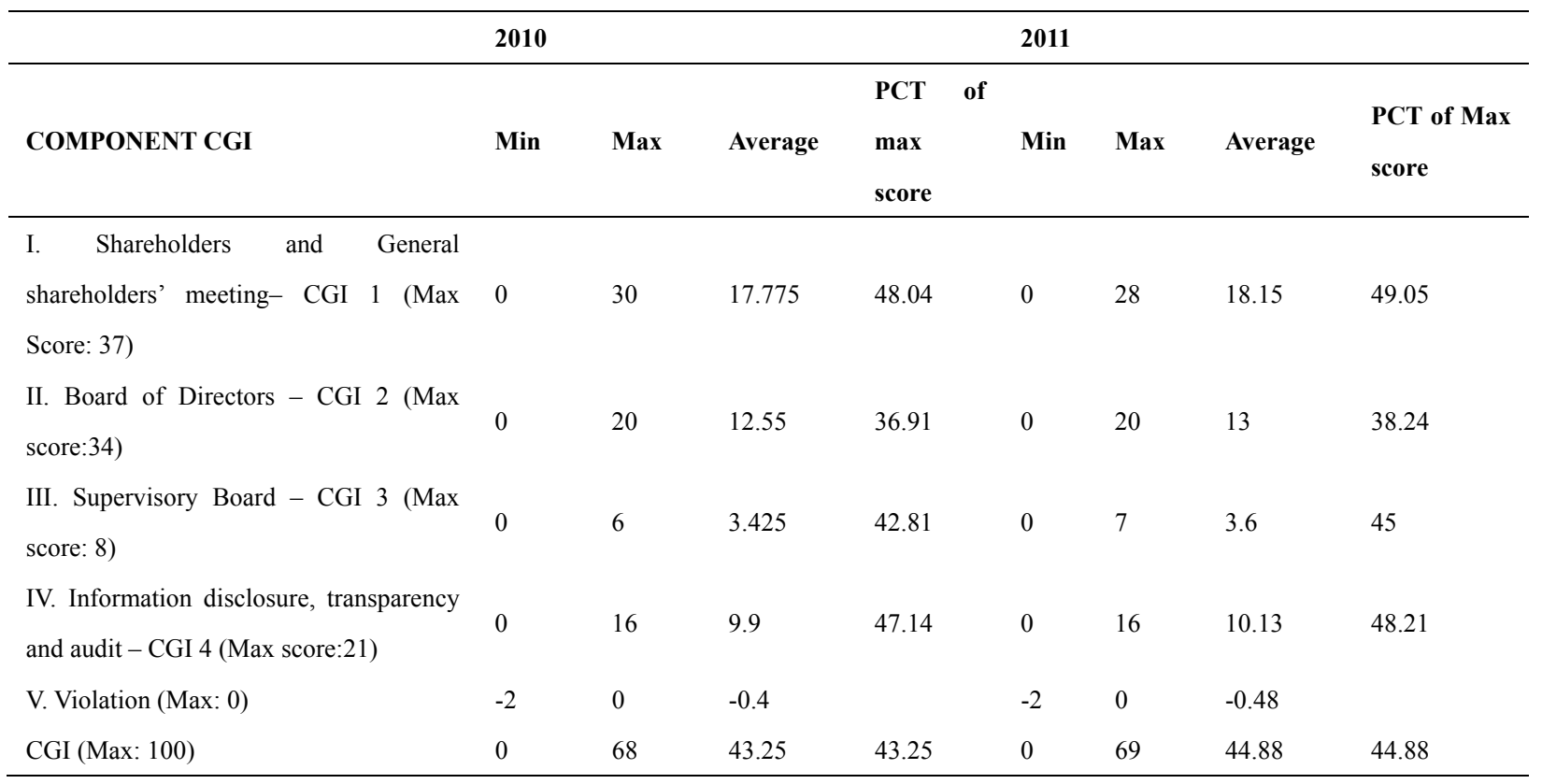

Table 2. Descriptive statistics of CGI (Con't)

\begin{tabular}{|c|c|c|c|c|}
\hline \multirow[b]{2}{*}{ COMPONENT CGI } & \multicolumn{3}{|l|}{2012} & \multirow[b]{2}{*}{$\begin{array}{l}\text { PCT } \\
\text { max } \\
\text { score }\end{array}$} \\
\hline & Min & $\operatorname{Max}$ & Average & \\
\hline I. Shareholders and General shareholders' meeting-CGI 1 (Max Score: 37) & 0 & 27 & 18.72 & 50.59 \\
\hline II. Board of Directors - CGI 2 (Max score:34) & 0 & 20 & 13.28 & 39.06 \\
\hline III. Supervisory Board - CGI 3 (Max score: 8) & 0 & 7 & 3.87 & 48.40 \\
\hline IV. Information disclosure, transparency and audit - CGI 4 (Max score:21) & 0 & 14 & 9.28 & 44.20 \\
\hline V. Violation (Max: 0) & -2 & 0 & -0.67 & \\
\hline CGI (Max: 100) & 0 & 67 & 44.49 & 44.49 \\
\hline
\end{tabular}

The law on credit institutions took effect in January 2010 with many changes in corporate governance. Yet, table 2 shows that corporate governance index of Vietnam banks from 2010 to 2012 has been below average i.e at 43/100 and 45/100. This level of CGI suggests that there are many weaknesses in corporate governance of Vietnamese banks and there is a big gap between international practices and Vietnamese ones. While there is a slight improvement from 2010 to 2011 , CGI in 2012 is unchanged as compared to 2011 . This result indicates that the bank restructuring program of the Government started in 2011 has not brought about any obvious effect.

Among 4 areas of corporate governance, role of board of directors was found to be the weakest, its CGI was at $37 / 100,38 / 100$ and 39/100 in 2010, 2011 and 2012 respectively. Lack of independence is found to be the main problem in corporate governance. Information form in-depth interviews with banks in Ho Chi Minh city 
conducted by the author in July 2013 also supports this finding. Most of decisions are made by directors and chairman of banks. Independent directors sit the board just for complying with regulation while many of them are not independent. Their decisions are heavily influenced by a group of dominant directors and chairman. This phenomenon is embedded in management in Vietnamese banks partly due to Asian culture in doing business which overemphasize the importance of personal relationship. Moreover, many private banks in Vietnam had been found by a group of relatives or friends so these groups control everything in the banks.

The second weakest area is supervisory board. They are required to be independent to the Board in order to supervise the Board. However, many of them are not independent in judging the board and bank performance due to their close relationship with the chairman or CEO. One of the reason for this problem is the same as for the board of directors problem explained just above.

The information disclosure, transparency and shareholders' meeting are all just below average but better than role of board of directors and supervisory board. Our in depth interviews with banks also support this finding. It is found in the interviews that information disclosed is inconsistent and incomparable. Especially, it is not transparent because not all investors can access the information timely. Those having close relationship with banks can get to know the information earlier than others - small investors. In fact, small investors trade with herding behavior so they are even not aware of their rights to information of banks. Moreover, many non-listed banks are very late at providing financial statements at the end of the year, normally, after the second quarter of the next year, they are published.

Table 3. Data description

\begin{tabular}{lcccccccccc}
\hline & ROE & ROA & COI & CGI & CGI 1 & CGI 2 & CGI 3 & CGI 4 & LEV & TA \\
\hline Mean & 11.42205 & 1.119187 & 81.31460 & 45.36364 & 18.80909 & 13.23636 & 3.772727 & 10.02727 & 10.76539 & 17.72876 \\
Median & 9.086579 & 1.067415 & 90.49500 & 46.50000 & 20.00000 & 14.00000 & 4.000000 & 10.00000 & 9.867966 & 17.65044 \\
Maximum & 57.62927 & 4.950000 & 106.0902 & 69.00000 & 30.00000 & 20.00000 & 7.000000 & 16.00000 & 37.91000 & 20.03715 \\
Minimum & 0.074980 & 0.009738 & 34.51339 & 0.000000 & 0.000000 & 0.000000 & 0.000000 & 0.000000 & 2.156274 & 15.92274 \\
Std. Dev. & 8.677465 & 0.753946 & 19.29150 & 12.93507 & 6.034299 & 4.637160 & 1.617899 & 2.836392 & 5.423337 & 1.048835 \\
Skewness & 2.022363 & 2.250383 & -1.044105 & -0.864993 & -0.775266 & -1.138470 & -0.215823 & -0.703871 & 1.831150 & 0.433317 \\
Kurtosis & 9.737178 & 11.45966 & 2.578207 & 4.130605 & 3.336897 & 4.077696 & 2.989119 & 5.152389 & 8.513938 & 2.270881 \\
Jarque-Bera & 283.0180 & 420.8543 & 20.80158 & 19.57598 & 11.53922 & 29.08529 & 0.854503 & 30.31652 & 200.8231 & 5.878892 \\
Probability & 0.000000 & 0.000000 & 0.000030 & 0.000056 & 0.003121 & 0.000000 & 0.652300 & 0.000000 & 0.000000 & 0.052895 \\
Sum & 1256.425 & 123.1106 & 8944.606 & 4990.000 & 2069.000 & 1456.000 & 415.0000 & 1103.000 & 1184.192 & 1950.164 \\
Sum Sq. Dev. & 8207.526 & 61.95932 & 40565.64 & 18237.45 & 3968.991 & 2343.855 & 285.3182 & 876.9182 & 3205.972 & 119.9059 \\
Observations & 110 & 110 & 110 & 110 & 110 & 110 & 110 & 110 & 110 & 110 \\
\hline
\end{tabular}

According to Jarque-Bera test, with significant level of 5\%, CGI 3 (Supervisory Board) are not normal distribution. However, with significant level of $10 \%$, CGI Supervisory Board is normal distribution. With the above description, regression of ROE, ROA with independent variables i.e CGI, CGI Shareholders (CGI 1), CGI Board of Directors (CGI 2), CGI Supervisory Board (CGI 3), CGI disclosure (CGI 4), LEV and TA is expected to acceptable. 
5.2 Research Results

\subsubsection{Results of Hypothesis 1}

Table 4. Regression result - coefficient

\begin{tabular}{|c|c|c|}
\hline Dep. Var & & thesis 1 \\
\hline & ROE & ROA \\
\hline Constant & $-42.9788 * * *$ & $2.3621^{*}$ \\
\hline CGI & $0.1802 * * *$ & $0.0198 * * *$ \\
\hline LEV & $-0.0637^{*}$ & $0.0258 * *$ \\
\hline TA & $2.6461 * * *$ & $-0.1343^{*}$ \\
\hline Prob (F-statistic) & 0.000001 & 0.0009 \\
\hline No. obs & 110 & 110 \\
\hline Constant & $-45.7245^{* * *}$ & 2.0052 \\
\hline CGI shareholders & $0.2859 * *$ & $0.0278 * *$ \\
\hline LEV & $-0.0375^{*}$ & $0.0288 * *$ \\
\hline TA & $2.9427 * * *$ & -0.0970 \\
\hline Prob (F-statistic) & 0.000003 & 0.011 \\
\hline No. obs & 110 & 110 \\
\hline Constant & $-50.2973 * * *$ & 1.5757 \\
\hline CGI Board of Directors & $0.4418 * * *$ & $0.0447 * * *$ \\
\hline LEV & $-0.0377 *$ & $0.0286^{* *}$ \\
\hline TA & $3.1743 * * *$ & -0.0766 \\
\hline Prob (F-statistic) & 0.000001 & 0.0021 \\
\hline No. obs & 110 & 110 \\
\hline Constant & $-48.1092 * * *$ & $2.5801 * *$ \\
\hline CGI Supervisory Board & $0.5700^{*}$ & $0.1312 * * *$ \\
\hline LEV & $-0.0377^{*}$ & $0.0246^{*}$ \\
\hline TA & $3.2595 * * *$ & -0.1253 \\
\hline Prob (F-statistic) & 0.000014 & 0.0037 \\
\hline No. obs & 110 & 110 \\
\hline Constant & $-47.5804 * * *$ & 1.8950 \\
\hline CGI Disclosure & $0.6504 * *$ & $0.0702 * * *$ \\
\hline LEV & $-0.0605^{*}$ & $0.0260^{*}$ \\
\hline TA & $2.9969 * * *$ & -0.0992 \\
\hline Prob (F-statistic) & 0.000002 & 0.004 \\
\hline No. obs & 110 & 110 \\
\hline
\end{tabular}

Note: Statistically significant at $* 10 \%, * * 5 \%, * * * 1 \%$.

Hypothesis 1: There is a positive relationship between corporate governance and bank performance

Finding 1: Corporate governance has positive impact on ROE

Result in table 4 shows that the regression ROE with composite CGI and other variables is statistically significant at $1 \%$ level. $26 \%$ of changes in ROE can be explained by corporate governance (CGI) and bank size (measure by total assets). 
Banks with higher composite CGI and higher total assets are identified with higher ROE, holding other variables constant. LEV is not accepted at 5\% significant level. It is found out from the model that when CGI increases by 1 point, average ROE would increase by 1 point. When total assets increases by $1 \%$, average ROE would increase by 2.646 point.

The above result suggests that better corporate governance (i.e more in line with OECD and Basel principles) can have positive impact on bank performance (measure by ROE).

Finding 2: Shareholders and shareholders meeting, role of board of directors, disclosure all have positive impact on ROE. The more regulations and practices of Shareholders and shareholders meeting, role of board of directors, disclosure are in line with international principles, the better the performance of the bank is.

Table 4 shows that shareholders and shareholder meeting have positive impact on ROE. It is found from the model that when CGI shareholders and shareholder meeting increases by 1 point, ROE increases by 0.28 basis point.

CGI Board of Directors is found to have positive impact on ROE. It is found from the model that when CGI Board of Directors increases 1 point, ROE increases by 0.44 basis point.

Supervisory board has positive impact on ROE. It is found from the model that when CGI Supervisory Board increases by 1 point, ROE increases by 0.57 basis point.

Disclosure has positive impact on ROE. It is found from the model that when CGI Disclosure increases by 1 point, ROE increases by 0.65 basis point.

Finding 3: Corporate governance has positive impact on ROA

According to to Table 4, the regression ROA with composite CGI and other variables is statistically significant at $1 \%$ level. Only $14 \%$ of changes in ROA can be explained by corporate governance (CGI) and asset size (total asset).

Banks with higher composite CGI and lower leverage are identified with higher ROA, holding other variables constant. TA is not accepted at 5\% significant level. It is found out from the model that when CGI increases by 1 point, average ROA would increase by 0.019 point.

The above result suggests that better corporate governance (i.e more in line with OECD and Basel principles) can have positive impact on bank performance (ROA).

Finding 4: Shareholders and shareholders meeting, role of board of directors, disclosure all have positive but small impact on ROA. When regulations and practices in shareholders, role of board of directors, disclosure are more in line with international principles, ROA of banks is expected to increase slightly.

The result in table 4 shows that when all 4 CGI components increases by 1 point, ROA is expected to increase slightly. As compared to regression result of ROE, impact of corporate governance on ROA is smaller than the impact on ROE. One of the possible implication is that better corporate governance can increase the return after tax thereby increasing ROE. At the same time, ROA can only be increased slightly if the asset of a bank is already very large compared to its equity. .

As the relation between corporate governance and bank performance is tested for 3 years from 2010 to 2012, the result may change subject to changes in financial market and economic condition over time. The result should be also treated with caution because number of observations is not large and it is necessary to continue testing CGI construction methodology in coming years. More variables should be included in the model in future study to improve R-square

5.2.2 Hypothesis 2, 3, 4

Hypothesis 2: There is a difference in corporate governance between listed and non listed banks

\begin{tabular}{llllll}
\hline & $\mathrm{N}$ & Mean & Std. Deviation & Minimum & Maximum \\
\hline Non listed & 82 & 41.74 & 12.154 & 0 & 60 \\
Listed & 27 & 56.37 & 8.607 & 38 & 69 \\
Total & 109 & 45.37 & 12.995 & 0 & 69 \\
\hline
\end{tabular}

Note: Levene test confirms the Homogeneity of Variances 


\section{ANOVA}

\begin{tabular}{lllllc}
\hline CGI & \multicolumn{1}{l}{} & & & \\
\hline & Sum of Squares & df & Mean Square & F & Sig. \\
Between Groups & 4345.403 & 1 & 4345.403 & 33.470 & .000 \\
Within Groups & 13891.918 & 107 & 129.831 & & \\
Total & 18237.321 & 108 & & & \\
\hline
\end{tabular}

The above results show that there is statistically difference between CGI of listed banks and non listed banks. Average CGI of listed banks are higher than CGI of non listed. This finding suggests that being listed can encourage banks to comply the central bank's regulation and international practices. Among about 40 banks, only 9 banks are listed. Therefore, regulations and policies should aim at encouraging banks to become listed.

Hypothesis 3: There is a difference in corporate governance between banks with larger equity and others.

\begin{tabular}{llllll}
\hline & $\mathrm{N}$ & Mean & Std. Deviation & Minimum & Maximum \\
\hline Below 142 million USD & 18 & 42.33 & 5.434 & 31 & 50 \\
142 million USD and above & 91 & 45.97 & 13.959 & 0 & 69 \\
Total & 109 & 45.37 & 12.995 & 0 & 69 \\
\hline
\end{tabular}

Note: Levene test confirms the Homogeneity of Variances

\begin{tabular}{llllll}
\hline \multicolumn{7}{c}{ ANOVA } \\
\hline CGI & Sum of Squares & df & Mean Square & F & Sig. \\
\hline Between Groups & 198.420 & 1 & 198.420 & 1.177 & .280 \\
Within Groups & 18038.901 & 107 & 168.588 & & \\
Total & 18237.321 & 108 & & & \\
\hline
\end{tabular}

According to the above tables, it cannot be confirmed that there is a statistically significant difference in corporate governance of banks whose equity is higher than 142 million USD and banks whose equity is less than 142 million USD. This result suggests that banks with larger capital do not necessarily have better corporate governance.

Hypothesis 4: There is a difference in corporate governance between banks with larger assets and others

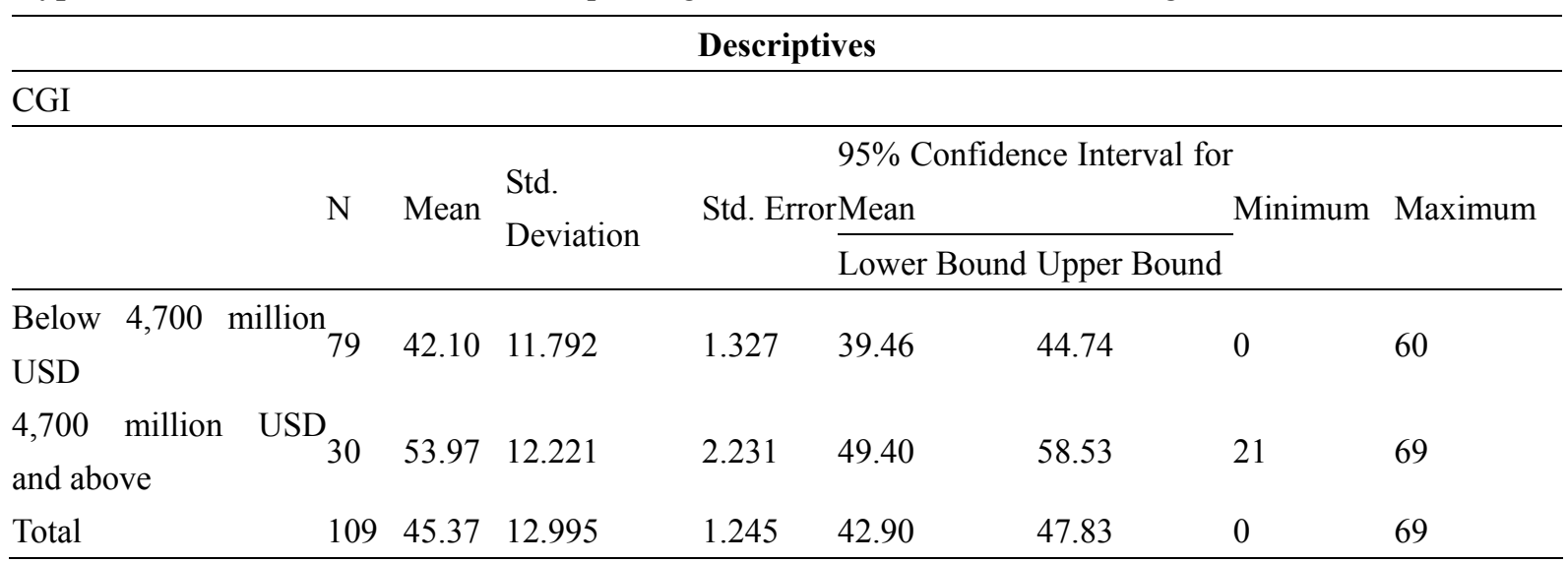

Note: Levene test confirms the Homogeneity of Variances 


\begin{tabular}{|c|c|c|c|c|c|}
\hline \multicolumn{6}{|c|}{ ANOVA } \\
\hline \multicolumn{6}{|l|}{ CGI } \\
\hline & Sum of Squares & df & Mean Square & $\mathrm{F}$ & Sig. \\
\hline Between Groups & 3061.165 & 1 & 3061.165 & 21.583 & .000 \\
\hline Within Groups & 15176.157 & 107 & 141.833 & & \\
\hline Total & 18237.321 & 108 & & & \\
\hline
\end{tabular}

The above table shows that there is statistically difference in corporate governance between banks whose asset is below 4,700 million USD and banks whose asset is 4,700 million USD and above. This indicates that banks with larger assets can have better corporate governance. This finding supports hypothesis 3 .

\section{Conclusions and Policy Implications}

\subsection{Conclusions}

CGI of the banks is found to be able to reflect corporate governance of the Vietnamese banks. Corporate governance has positive impact on bank performance. Shareholders and shareholders meeting, role of board of directors, disclosure are found to have positive impact on ROA and ROE.

It is found that even for a medium to large bank, established after privatization and unaffected by state management style under centrally planned economy, its corporate governance just observed half of OECD, Basel principles and central bank's regulation. This result indicates that a lot of effort has to be made if Vietnam would like to really integrate into the international financial system.

Supervisory board and board of directors are the weakest in the bank's corporate governance. This weakness is not difficult to identify but if no measures are taken timely, it will have detrimental impact on confidence of the investors in regulators and government policies.

The above findings add another empirical evidence of positive impact of corporate governance on bank performance in an Asian developing country. They support the literature of the supervisory and independent role of the Board of directors, transparency and disclosure in banks. These findings also confirm the benefits of using board of directors as a model to control the conflict of interests between owners and managers as proposed by agency theory.

\subsection{Policy Implication}

With the above result, the following policy implications can be made for the Vietnam banking system at present:

Corporate governance practices of Vietnam banks are far below international standard. Supervisory board and Board of directors are found to be the weakest areas in corporate governance.

From 2010 to 2012, although there have been many changes in regulations and restructuring project in place, no significant improvement in corporate governance has been seen. CGI for the 3 years are at $43 / 100$ to $45 / 100$ level.

Corporate governance has positive impact on bank performance, especially three components including shareholders, board of directors and disclosure. Therefore, policy measures should focus more on improving the corporate governance practices of Vietnamese banks, filling the gap with international standards.

As listed banks have better corporate governance non listed banks, policy should aim at encouraging banks to become listed. Banks with larger asset have better corporate governance but the result should be treated with caution. When asset is increased, banks should make sure that improvement in corporate governance should be large enough so that assets are managed effectively to generate higher return and ROA.

As banks with higher capital does not necessarily have better corporate governance, so increasing the capital does not mean that bank performance will be better but it is the corporate governance - among other factors that can have positive impact on bank performance.

CGI could be applicable in Vietnamese banks and should be used as an indicator to evaluate corporate governance practices for policy makers as well as bank managers. Authorities should apply this CGI periodically in bank assessment which can promote transparency and enhance investors' confidence.

Bank performance measured by ROE is improved more by expanding assets than by improving corporate governance. This development may be not sustainable in current international economic downturn and in the 
long term. Marginal effect in ROE that asset expansion can bring about can be diminishing overtime. Expanding asset is not a sustainable source of development of the Vietnam banking system.

Financial regulators should encourage banks to increase the shareholder's right, board independence and oversight and especially transparency and information disclosure to increase the bank efficiency.

\subsection{Limitations and Further Research}

This paper tries to test the relationship between CGI and CGI components to bank efficiency in Vietnam, many other variables will affect to bank performance such as: human resource, ownership, net-work branches etc... are not included in the model. Besides, the authors proposed CGI to estimate the corporate governance of 44 Vietnamese banks only in 2 years, it should be extended for longer period so that could bring more meaningful for policy makers and practitioners. Therefore, it is necessary to have more time and fund to conduct a more comprehensive study about this issue in the context of bank restructuring in Vietnam nowadays.

\section{References}

Abdul Rahman, R. (2006). Effective Corporate Governance. UPENA publication.

Abdul Rahman, R., \& Rizal Salim, M. (2010). Corporate governance in Malaysia: Theory, law, and context. Sweet \& Maxwell Asia publication.

Anderson, A., \& Gupta, P. (2009). A cross - country comparison of Corporate Governance and Firm Performance: Do Financial structure and the Legal System Matter? Journal of Contemporary Accounting and Economics. Japan Corporate

Anderson, C. W., \& Campbell, T. L. (2004). Corporate governance of Japanese banks. Journal of Corporate Finance. http://dx.doi.org/10.1016/S0929-1199(03)00029-4

Andres, P., \& Vallelado, E. (2008). Corporate governance in banking: The role of the board of directors. Journal of Banking \& Finance, 32, 2570-2580. http://dx.doi.org/10.1016/j.jbankfin.2008.05.008

Black, B., Jang, H., \& Kim, W. (2003). Does Corporate Governance affect firm value? Evidence from Korea.

Brown, L., \& Caylor, M. (2004). Corporate governance and firm performance. Working Paper, Georgia State University, 28-32.

Cung, N. D., \& Scott, R. (2005). Corporate Governance in Vietnam. William Davidson Institute, University of Michigan.

Daines, R., Gow, I., \&Larcker, D. (2009). Rating the Ratings: How Good are Commercial Governance Ratings? Rock Center for Corporate Governance at Stanford University, Working Paper Series No. 1, Stanford University School of Law, Law \& Economics Research Paper Series, Paper No. 360.

Epps, R., \& Cereola, S. (2008). Do institutional shareholder services (ISS) corporate governance ratings reflect a company's operating performance? Critical Perspectives on Accounting, 19(8), 1135-1148. http://dx.doi.org/10.1016/j.cpa.2007.06.007

Gompers, P., Ishii, J., \& Metrick, A. (2003). Corporate governance and equity prices. Quarterly Journal of Economics, 118(1). http://dx.doi.org/10.1162/00335530360535162

Governance Research Institute. (2008). Reports of annual JCGR survey on corporate governance in Japan: 2002-2008.

Hermalin, B. E., \& Weisbach, M. S. (1991). The effect of board composition and direct incentives on firm performance. Financial Management, 20, 101-112. http://dx.doi.org/10.2307/3665716

International Finance Corporation, The Global Corporate Governance Forum and The State Securities Commission of Vietnam. (2011). Corporate Governance Scorecard of Vietnam 2011.

Le et al. (2009). Corporate governance in Vietnam. Does it really works? National Economics University.

Lowenstein, L. (1996). Financial transparency and Corporate Governance. Columbia Law Review, 96.

Marina, M., \& Luc, R. (2010). A Corporate Governance Index: Convergence and Diversity of National Corporate Governance Regulations. Discussion Paper 2010-17, Tilburg University, Center for Economic Research.

Mohanty, P. (2011). The link between corporate governance and firm performance - Evidence from India. International centre for financial regulation.

OECD. (2006). Principles of Corporate governance. 
Pan, P. S. (2004). Review of literature \& Empirical Research on Corporate Governance. MAS staff paper, Monetary Authority of Singapore.

Son, N. H., \& Tu, T. T. T. (2013). Bank restructure - international perspective and Vietnamese practices. World finance conference, Beijing, December 2013.

Thang, T. N. (2010). Building corporate governance index. Ministerial Research project, Ministry of Education and Training.

The business Times and Center for Governance, Institutions and Organizations. (2011). Governance and transparency Index - GTI.

$\mathrm{Tu}$, T. T. T., \& Khanh, P. B. (2010). The role of the Board of Director - Case studies of Vietnamese banks. Social and Labor Publisher.

Tu, T. T. T., \& Khanh, P. B. (2012). Developingon corporate governance index of Vietnam commercial banks. Journal of Economic Development, 3.

Vincent et al. (2012). Risk management, corporate governance and bank performance in the financial crisis. International Journal of business and Management, 7(22).

World Bank. (2006). Report on the Observance of Standards and Codes. Corporate Governance Country Assessment, Vietnam.

\section{Notes}

Note 1. The Bank's charter 2010, 2011 (updated).

Note 2. Guidelines and policies for management, governance and operation.

Note 3. Reports on operation and financial condition $(2010,2011)$.

\section{Copyrights}

Copyright for this article is retained by the author(s), with first publication rights granted to the journal.

This is an open-access article distributed under the terms and conditions of the Creative Commons Attribution license (http://creativecommons.org/licenses/by/3.0/). 